\title{
EPISTEMOLOGI AHLI WARIS PENGGANTI DALAM KOMPILASI HUKUM ISLAM
}

\author{
Hajar M. \\ Fakultas Syariah dan Hukum UIN Suska Riau
}

\section{ABSTRACT}

Kompilasi Hukum Islam (KHI) regarded as ijma of Indonesian 'ulama figh schools were formulated through the study of the books of figh, interviews with scholars, jurisprudence and comparative study in Muslim-majority countries. Substantially, KHI includes legal reform, among others, the heir replacement in Article 185. The existence of substitute heirs still polemical, both in terms of the origin and validity. Heir replacement in KHI formulated through the jurisprudence derived from customary law derived from the Civil Code Napoleon in France. Substitute heirs grown in resolving inheritance cases, both at the level of the heirs, the level of customary deliberation and the judiciary. Results of this study showed that the presence of substitute heirs is a culture that is not based on faith, contrary to the principle of fairness, the principle ijbari, not in line with elements of inheritance and also contrary to the principle of the primacy and hijab. Heir replacement in $\mathrm{KHI}$ needs to be revisited.

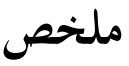

بحموعة الشريعة الإسلامية (KHI)تعتبر إجماععلماء الفقه الاندونيسيين من خلال دراسة كتب الفقه، ومقابلات مع علماء الفقه ودراسة مقارنة في البلدان التي أكثر بحتمعها مسلمون. إلى حد كبير، تشمل بحموعة الشريعة الإسلامية (KHI) التجديد

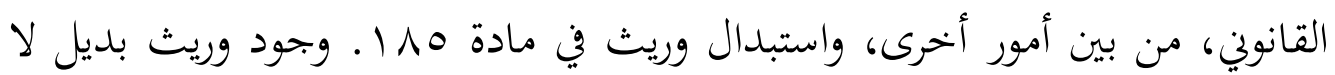
يزال انفعالي، سواء من حيث أصل وصحة. استبدال وريثفي بحموعة الشريعة الإسلامية (KHI) وضع من خلال فقه مستمد من القانون العرفي المستمد من قانون نابليون المدني في فرنسا. وريث بديل نما في حل قضايا الميراث، سواء على مستوى ورثة، ومستوى التداول العرفي والقضاء. وأظهرت نتائج هذه الدراسة أن وجود وريث 


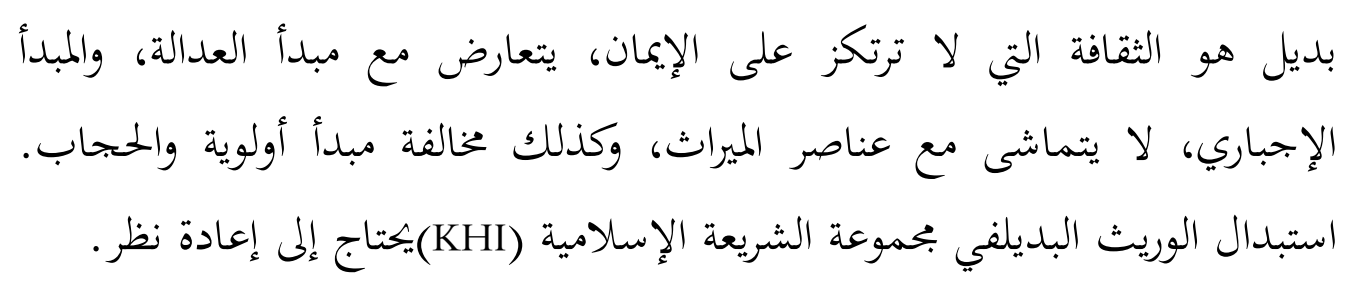

Keywords: KHI, ahli waris pengganti, revisi, pembaharuan.

\section{A. Pendahuluan}

Sejarah penyusunan Kompilasi Hukum Islam (KHI) di Indonesia mengalami tiga periode, yaitu sejak awal Islam masuk ke Indonesia sampai tahun 1945, periode dari tahun 1945 sampai tahun 1985, dan sejak tahun 1985 dengan dikeluarkan Instruksi Presiden RI Nomor 1 tanggal 10 Juni 1991. ${ }^{1}$

Penyusunan KHI periode terakhir sebenarnya dimulai pada tahun 1983, yaitu sejak penandatanganan Surat Keputusan Bersama (SKB) Ketua Mahkamah Agung RI dan Menteri Agama RI tentang penunjukan pelaksana proyek pembangunan hukum Islam melalui yurisprudensi, guna keseragaman dan menjadi rujukan para hakim pada pengadilan Agama. Panitia bekerja selama lebih kurang lima tahun, dan pada tahun 1988 rumusan KHI siap untuk diajukan kepada pemerintah dalam rangka proses menuju legalitas sebuah aturan hukum perundang-undangan. Selama tiga tahun lebih dalam masa penantian menunggu tindak lanjut nasib rancangan aturan KHI tersebut, belum juga ada titik terangnya. Akhirnya pada tanggal 10 Juni 1991, Presiden Soeharto menandatangani Instruksi Presiden (Inpres) Republik Indonesia Nomor 1 Tahun $1991 .^{2}$

Dalam konsideran Inpres tersebut dinyatakan beberapa klausul materi hukum, antara lain bahwa 'alim ulama Indonesia dalam lokakarya yang diadakan di Jakarta pada tanggal 2 sampai 5 februari 1988 telah menerima baik

1 Hasan Basri, dkk, Majalah Bulanan Mimbar Ulama, Dewan Pimpinan Majelis Ulama Indonesia, Edisi Bulan Juli 1992, Jakarta, 1992, hal. 43-44. Amin Husein Nasution, Hukum Kewarisan: Suatu Analisis Komparatif Pemikiran Mujtahid dan Kompilasi Hukum Islam, PT. Raja Grafindo Persada, Jakarta, 2012, hal. 1-9.

2 Habiburrahman, Rekonstruksi Hukum Kewarisan Islam di Indonesia, Kencana, Jakarta, Cetakan 1, 2011, hal. 53. 
tiga rancangan buku Kompilasi Hukum Islam, yaitu Buku I tentang hukum perkawinan, Buku II tentang hukum kewarisan dan Buku III tentang hukum perwakafan. Atas dasar itu pula kalangan masyarakat merespon KHI tersebut dengan penuh suka cita dan bangga karena merupakan buah karya 'alim ulama di Indonesia. ${ }^{3}$

Setelah Inpres disosialisasikan ke berbagai provinsi di Indonesia, terutama di kalangan ulama, tokoh agama dan tokoh masyarakat, muncul sanggahansanggahan tentang berbagai hal, antara lain di bidang hukum perkawinan terdapat aturan tentang kebolehan menikahkan wanita hamil. Dalam bidang kewarisan terdapat ahli waris pengganti dan anak angkat yang mendapat wasiat wajibah. Terhadap sanggahan tersebut, pejabat dari lingkungan Mahkamah Agung RI yang menjadi nara sumber menjelaskan bahwa KHI memang masih ada kelemahan dan kekurangan, namun hendaklah dapat diterima dulu apa adanya sambil berjalan diusahakan dan dipikirkan konsep-konsep perbaikan untuk masa yang akan datang. ${ }^{4}$

Keberadaan ahli waris pengganti terdapat pada Pasal $185 \mathrm{KHI}$, yaitu:

(1). "Ahli waris yang meninggal lebih dahulu dari pada si pewaris maka kedudukannya dapat digantikan oleh anaknya, kecuali mereka yang tersebut dalam Pasal 173". (2). "Bagian ahli waris pengganti tidak boleh melebihi dari bagian ahli waris yang sederajat dengan yang diganti".

Berdasarkan Pasal 185 KHI, cucu dapat mewarisi bersama anak laki-laki dan anak perempuan. Mereka tidak ditutup oleh anak laki-laki, karena berstatus menggantikan ayah atau ibu mereka yang telah meninggal lebih dahulu. Misalnya seseorang meninggal, di antara ahli waris adalah cucu yang ayah atau ibu mereka sudah meninggal lebih dahulu dari pewaris. Pewaris juga meninggalkan anak laki-laki dan anak perempuan. Cucu tersebut dapat menggantikan kedudukan ayah atau ibu mereka yang sudah meninggal untuk menerima harta warisan dari kakek atau nenek. Untuk lebih jelasnya dapat diperhatikan bagan berikut ini.

3 Departemen Agama RI, Himpunan Peraturan Perundang-undangan dalam Lingkungan Peradilan Agama, Proyek Peningkatan Pelayanan Aparatur Hukum, Jakarta, 2004, hal. 303.

4 Habiburrahman, Op cit, hal. 53-54. 


\section{Bagan 1}

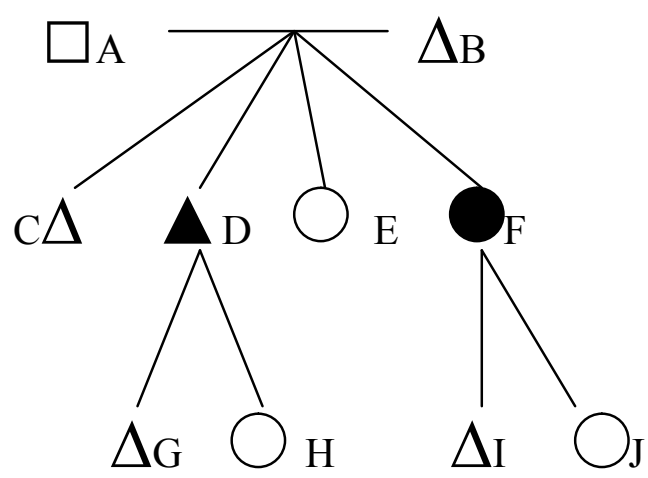

Berdasarkan bagan di atas, seorang nenek (B) meninggal dunia dengan meninggalkan suami/kakek (A), 2 orang anak laki-laki (E dan F), 2 orang anak perempuan (C dan D), serta 4 orang cucu (G, H, I, dan J). Seorang anak lakilaki (F) dan seorang anak perempuan (D) telah meninggal lebih dahulu dari pewaris (B). D mempunyai 2 orang anak, laki-laki (H) dan perempuan (G). Demikian pula $\mathrm{F}$ meninggal lebih dahulu dari $\mathrm{B}$, dan mempunyai anak, laki-laki (J) dan perempuan (I). Keempat orang cucu ini masing-masing berstatus menggantikan kedudukan ayah dan ibu yang telah lebih dahulu meninggal untuk menerima harta warisan nenek. ${ }^{5}$

Pada contoh bagan tersebut, penyelesaiannya adalah dengan menjadikan asal masalahnya 72. Suami/kakek memperoleh 18/72, seorang anak laki (E) memperoleh 18/72, seorang anak laki-laki (F) yang telah meninggal lebih dahulu dari B memperoleh 18/72, seorang anak perempuan (C) memperoleh $9 / 72$, dan seorang anak perempuan (D) yang telah meninggal lebih dahulu dari B memperoleh 9/72.

Hak kewarisan yang diperoleh F diwariskan kepada anaknya I (perempuan) dengan perolehan 6/72, dan J (laki-laki) memperoleh 12/72. Adapun hak kewarisan D diwariskan pula kepada anaknya, yaitu $\mathrm{H}$ (laki-laki) mendapat 6/72 dan G (perempuan) menerima 3/72.

Asal mula keberadaan ahli waris pengganti dapat ditelusuri metode perumusan yang digunakan dalam KHI. Pertama, pengkajian kitab-kitab fiqh,

5 Bandingkan Rachmad Budiono, Pembaruan Hukum Kewarisan Islam di Indonesia, PT. Citra Aditya Bakti, Bandung, Cet. 1, 1999, hal. 81. 
khususnya ketiga belas kitab fiqh yang telah berlaku selama ini di lingkungan Pengadilan Agama. Kedua, jalur ulama yang diwakili oleh sepuluh ibukota propinsi di Indonesia. Para ulama itu diwawancarai berbagai masalah hukum yang akan dituangkan dalam KHI. Ketiga, jalur studi perbandingan ke negaranegara yang penduduknya beragama Islam tentang hukum dan penerapan hukum Islam yang mereka lakukan. Keempat, melalui yurisprudensi, yaitu yang ada sejak masa kolonial sampai saat penyusunan KHI. Yurisprudensi itu dikaji, dipelajari, dan kemudian diambil garis hukum yang terkandung didalamnya. ${ }^{6}$

Metode perumusan KHI melalui yurisprudensi, terutama dimaksudkan yurisprudensi lembaga peradilan yang memberlakukan hukum Islam dan hukum adat. Keberadaan ahli waris pengganti dalam KHI diduga berasal dari hukum adat yang telah menjadi putusan hukum pada lembaga peradilan di Indonesia. Hukum adat yang berlaku diperkuat oleh Cornelis van Vollenhoven (1874-1933) dan Christiaan Snouck Hurgronje (1857-1936). ${ }^{7}$ Hukum adat kemudian dipertajam ke dalam batin bangsa Indonesia melalui pendidikan yang kontinuitas. ${ }^{8}$

Hukum adat yang terdapat dalam KHI sangat dimungkinkan adopsi dari Hukum perdata $(B W)$ yang berlaku sejak tahun $1847 .{ }^{9}$ Dalam tata hukum Belanda, kodifikasi dikenal pada masa ekspansi kekuasaan Napoleon yang menyebabkan negeri Belanda teraneksasi sebagai bagian dari empirium Perancis. Pada tahun 1810 kitab hukum yang terkenal dengan nama Codes Napoleon dalam hukum perdata (code civil) diundangkan di negeri yang teraneksasi ini oleh peguasa. Ketika kekuasaan Napoleon runtuh, hukum hasil kodifikasi Napoleon tetap berlaku di negeri Belanda. ${ }^{10}$

6 Abdurrahman, Kompilasi Hukum Islam di Indonesia, Akademika Pressindo, Jakarta, Cet. 4, 20004, hal. 36-39. Amin Husein Nasution, Op cit, hal. 15-33. Mohammad Daud Ali, Hukum Islam dan Peradilan Agama, PT. Raja Grafindo Persada, Jakarta, Cet. 1, 1997, hal. 115-116.

7 Sajuti Thalib, Receptio A Contrario (Hubungan Hukum Adat dengan Hukum Islam), Bina Aksara, Jakarta, cet. 4, 1985, hal. 9

8 Habiburrahman, Op cit, hal. 63.

9 Kitab Undang-Undang Hukum Perdata pada mulanya berlaku bagi kalangan Eropa di Hindia Belanda, namun diupayakan untuk diunifikasi secara bewuste rechtspolitiek. Soetandyo Wignjosoebroto, Dari Hukum Kolonial Ke Hukum Nasional, PT. Raja Grafindo Persada, Jakarta, Cet. 2, 1995, hal. 47.

10 Ibid, hal. 40. 
Pada sisi lain, ahli waris pengganti berasal dari pemikiran Hazairin, yaitu setiap ahli waris yang menggantikan seseorang yang lebih dahulu meninggal dunia untuk memperoleh bagian kewarisan. ${ }^{11}$ Ahli waris pengganti yang dikemukakan Hazairin berasal dari sumber al-Qurān surat an-Nisa' ayat 33 yaitu:

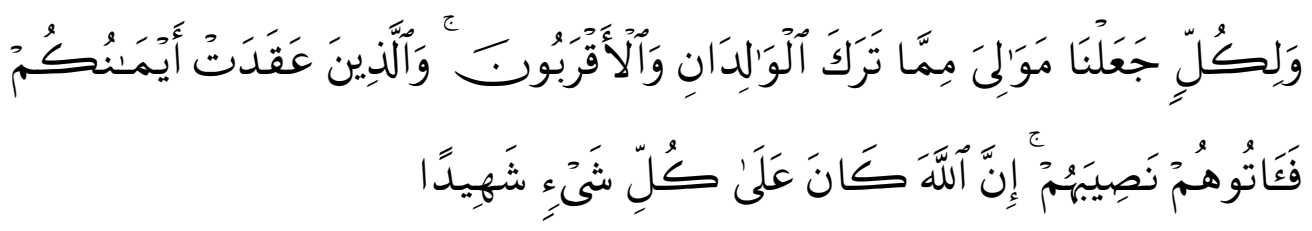

Menurut Hazairin, lafazh al-wālidāni wa al-aqrabūna adalah sebagai fa'il dari lafazh taraka. Sedangkan lafazh mawāliya adalah sebagai maf'ul bagi ja'alna. ${ }^{12}$ Artinya, setiap harta yang ditinggalkan oleh ibu bapak dan kerabat terdekat, dijadikan Allah ahli waris-ahli warisnya. Allah menjadikan ahli waris sebagai pengganti dari ahli waris yang telah meninggal lebih dahulu. ${ }^{13}$

Berdasarkan fenomena diatas, artikel ini mengkaji epistemologi ahli waris pengganti dalam KHI, yaitu asal mula ahli waris pengganti, perkembangan dan kedudukan ahli waris pengganti dalam hukum kewarisan.

\section{B. Asal usul ahli waris pengganti}

Awal keberadaan ahli waris pengganti yang terdapat dalam Pasal $185 \mathrm{KHI}$ dapat ditelusuri dari metode perumusan KHI. Di antara metode perumusan KHI adalah melalui jalur yurisprudensi yang dilakukan oleh Direktorat Pembinaan Badan Peradilan Agama terhadap putusan Pengadilan Agama yang telah dihimpun dalam 16 (enam belas) buku, yaitu:

1. Himpunan putusan PA/PTA 4 (empat) buku yang diterbitkan tahun 1976/1977, 1977/1978, 1978/1979 dan 1980/1981.

2. Himpunan fatwa terdiri dari 3 (tiga) buku yang diterbitkan tahun 1978/1979, 1979/1980 dan 1980/1981.

3. Yurisprudensi PA 5 (lima) buku, yaitu terbitan tahun 1977/1978, 1978/1979, 1981/1982, 1982/1983 dan 1983/1984.

11 Hazairin, Hukum Kewarisan Bilateral Menurut Qur'an dan Hadith, Tinta Mas, Jakarta, Cet. 5, 1981, hal. 32.

${ }^{12}$ Ibid, hal. 49.

13 Ibid, hal. 30. 
4. Law report 4 (empat) buku yang terbit tahun 1977/1978, 1978/1979, 1981/1982 dan 10983/1984..$^{14}$

Yurisprudensi di atas menjadi salah satu sumber pembentukan hukum di Indonesia. Hukum kewarisan yang berlaku di Pengadilan Agama umumnya mengacu kepada hukum Islam, hukum adat dan hukum Barat. Di antara putusan masalah waris, seperti ahli waris pengganti cenderung tidak mengacu kepada al-Qurān dan hadis, tetapi menggunakan pertimbangan hukum yurisprudensi yang ditetapkan melalui hakim pada pengadilan lain. ${ }^{15}$ Misalnya, kasus kewarisan yang menetapkan adanya ahli waris pengganti pada Pengadilan Agama Donggala dalam perkara Amboelu. ${ }^{16}$

Yurisprudensi tentang ahli waris pengganti pada intinya berdasarkan pada hukum yang hidup (living law) sejak ratusan tahun yang lalu dipraktekkan secara sukarela dan memuaskan pihak-pihak yang melaksanakannya. ${ }^{17}$ Masyarakat sudah melaksanakan aturan tentang ahli waris pengganti, baik melalui musyawarah ahli waris, melalui musyawarah dewan adat, melalui Pengadilan Negeri maupun Pengadilan Agama. ${ }^{18}$

Berdasarkan politik hukum pada masa pemerintahan Hindia Belanda, pelaksanaan hukum Islam diupayakan diganti dengan hukum adat. Melaksanakan hukum adat sebagai suatu yang benar dan hukum Islam itu bukan hukum di Indonesia. Persepsi seperti ini dibudayakan dalam kehidupan masyarakat, bahkan ada kesan bahwa pelaksanaan hukum adat itu dimulai sejak tahun 1855 melalui Stbl. 1855 Nomor 2. ${ }^{19}$

Ahli waris pengganti yang terdapat dalam hukum adat sebenarnya sudah ada dalam hukum perdata (BW) yang berlaku sejak tahun 1847. Pasal 841 dan

14 Direktorat Pembinaan Badan Peradilan Agama, Kompilasi Hukum Islam di Indonesia, Direktorat Pembinaan Badan Peradilan Agama Direktorat Jenderal Pembinaan Kelembagaan Agama Islam Departemen Agama RI, Jakarta, 1991/1992, hal. 152. Abdurrahman, Op cit, hal.43-44. Ahmad Rofiq, Pembaharuan Hukum Islam di Indonesia, Gama Media, Cet. 1, Jakarta, 2001, hal. 92.

15 Habiburrahman, Op cit, hal. 95.

16 Kasus ahli waris pengganti Amboelu secara rinci dapat dilihat dalam Zainuddin Ali, Pelaksanaan Hukum Waris di Indonesia, Sinar Grafika, Cet. 1, Jakarta, 2008, hal. 210-211.

17 Ahmad Rofiq, Op cit, hal. 132.

18 Zainuddin Ali, Op cit, hal. 154.

19 Sajuti Thalib, Op cit, hal. 39. 
842 berbunyi:

Pasal 841, "Pergantian memberi hak kepada seorang yang mengganti, untuk bertindak sebagai pengganti, dalam derajat dan dalam segala hak orang yang diganti". Pasal 842 "Pergantian dalam garis lurus ke bawah yang sah, berlangsung terus dengan tiada akhirnya". Dalam segala hal, pergantian seperti di atas selamanya diperbolehkan, baik dalam hal bilamana beberapa anak si yang meninggal mewaris bersama-sama dengan keturunan seorang anak yang telah meninggal terlebih dahulu, maupun sekalian keturunan mereka mewaris bersama-sama, satu sama lain dalam pertalian keluarga yang berbeda-beda derajatnya" ${ }^{20}$

Secara umum aturan dalam hukum perdata Belanda ini diberi kesempatan bagi masyarakat pribumi secara sukarela melaksanakannya melalui vrijwilige onderwerping dan toepasselijk verklaring. Cara seperti ini menurut Scholten van Oud-Haarlem merupakan upaya hukum yang dapat diwujudkan. ${ }^{21}$ Scholten yang diangkat sebagai ketua komisi kerja perundang-undangan di Hindia Belanda berusaha segera mempersiapkan kodifikasi hukum untuk daerah jajahan Belanda, dan upaya itu berhasil dengan menuangkan gagasan-gagasan tentang introduksi kodifikasi hukum Belanda ke wilayah jajahan. ${ }^{22}$

Di sisi lain, Scholten tetap mempositifkan hukum Islam melalui Pasal 75 dan Pasal 78 Reglement op het beleid der Regeering van Nederlandsch yang disingkat dengan $R R$, yaitu peraturan perundang-undangan yang menjadi dasar pemerintahan Hindia Belanda. ${ }^{23}$ Sehubungan dengan itu, diresmikan pula pendirian lembaga peradilan Agama melalui Stbl. 1882 Nomor 152.

Pendirian lembaga peradilan Agama ini sebenarnya merugikan pelaksanaan hukum kewarisan Islam, karena setiap putusan peradilan Agama terutama dalam kasus kewarisan terlebih dahulu dikukuhkan (executoir verklaring) oleh pengadilan Negeri. ${ }^{24}$

${ }_{20}$ R. Subekti dan R. Tjitrosudibio, Kitab Undang-Undang Hukum Perdata, Pradnya Paramita, Cetakan ke-40, Jakarta, 2009, hal. 224.

21 Soetandyo Wignjosoebroto, Op cit, hal. 56.

22 Hajar M, Dimensi Hukum Kewarisan Islam di Indonesia, Suska Press, Cet. 1, Pekanbaru, 2008, hal. 24-25.

23 Soetandyo Wignjosoebroto, Op cit, hal. 56-59.

24 Putusan Pengadilan Agama tidak dikukuhkan jika tidak memenuhi syarat sebagaimana ditetapkan. Syarat-syarat tersebut lihat antara lain M. Djamil Lathif, Kedudukan dan kekuasaan Peradilan Agama di Indonesia, Bulan Bintang, Cet. 1, Jakarta, 1983, hal. 17-18. 
Realisasi putusan pengadilan Agama dalam kasus waris tidak dapat diberi kekuatan hukum oleh pengadilan Negeri, meskipun putusan itu tidak melanggar persyaratan yang ditetapkan. Oleh sebab itu, kasus kewarisan itu diperiksa lagi oleh pengadilan Negeri memberlakukan hukum perdata dengan dalih hukum adat. Selain itu, hasil pemeriksaan ulang dari pengadilan Negeri tidak dapat dimintakan banding meskipun pihak yang berperkara tidak merasa puas. ${ }^{25}$

Keberadaan ahli waris pengganti dalam KHI bermula dari hukum adat. Ahli waris pengganti yang terdapat dalam hukum adat berasal dari hukum perdata Belanda. Cara yang diterapkan pemerintah Hindia Belanda sehingga ahli waris pengganti menjadi bagian dari hukum adat pribumi adalah melalui bewuste rechtspolitiek. Wujud dari bewuste rechtspolitiek terdiri dari dua kebijakan, yaitu:

1. Vrijwillige onderwerping, yaitu suatu kesempatan yang diberikan kepada penduduk pribumi untuk secara sukarela tunduk kepada hukum Eropa;

2. Toepasselijk verklaring, yaitu memberikan kewenangan kepada Gubernur Jenderal untuk menerapkan peraturan perundang-undangan tertentu kepada penduduk pribumi. ${ }^{26}$

Cara lain untuk mendukung kebijakan di atas adalah dengan memberi kesempatan pada pengadilan Negeri untuk mengukuhkan putusan pengadilan Agama melalui executoir verklaring. Wujud dari kebijakan ini bahwa setiap putusan pengadilan Agama dalam perkara kewarisan diperiksa ulang oleh pengadilan Negeri dengan menerapkan hukum perdata dan adat.

Asal mula hukum perdata $(B W)$ Belanda adalah dari code civil Napoleon Perancis. Dalam tata hukum Belanda, kodifikasi dan hukum kodifikasi dikenal pada masa ekspansi kekuasaan Napoleon yang menyebabkan negeri Belanda teraneksasi sebagai bagian dari empirium Perancis. Pada tahun 1810 kitab hukum yang dikenal dengan Codes Napoleon yang memuat hukum perdata, hukum dagang dan hukum pidana diundangkan di negeri Belanda sebagai hukum yang berlaku. Setelah kekuasaan Napoleon runtuh, kitab hukum tersebut tetap berlaku di negeri Belanda. ${ }^{27}$

\footnotetext{
25 Ibid, hal. 17.

26 Soetandyo Wignjosoebroto, Op cit, hal. 56.

27 Ibid, hal. 40.
} 
Undang-undang Perancis menggunakan sistem penggantian, yaitu memberi bagian kewarisan kepada ahli waris yang lebih jauh dari ahli waris yang lebih dekat, karena dia telah meninggal terlebih dahulu. Misalnya, Zaid mempunyai dua orang anak laki-laki yaitu Khalid dan Ahmad. Khalid setelah kawin mempunyai dua orang anak laki-laki yaitu Muhammad dan Ibrahim. Khalid meninggal dan meninggalkan Muhammad dan Ibrahim. Kemudian Zaid meninggal dengan meninggalkan anaknya Ahmad dan kedua cucunya. Jika diperlakukan ketentuan bahwa ahli waris yang lebih dekat menutup ahli waris yang lebih jauh, maka Ahmad akan memperoleh semua harta peninggalan Zaid, sedangkan Muhammad dan Ibrahim tidak mendapat apa-apa. Akan tetapi, undang-undang tidak memberlakukan yang demikian itu, melainkan memberikan kepada Muhammad dan Ibrahim bagian ayah mereka sekiranya dia masih hidup. Inilah sistem penggantian hukum Perancis, berlaku bagi garis keturunan ke bawah tanpa batas. ${ }^{28}$

Jika ditelusuri lagi, bahwa hukum kewarisan Perancis merupakan peninggalan dari hukum Romawi. Wirjono Prodjodikoro mengungkapkan bahwa:

"Peraturan yang dulu itu, yang sesuai dengan Burgerlijk Wetboek di negeri Belanda dulu, adalah turunan dari Hukum Romawi, kemudian diadopsi oleh Perancis menjadi Kode Civil dari Raja Napoleon di Perancis". ${ }^{29}$

Dari uraian di atas dapat dipahami bahwa ahli waris pengganti yang terdapat dalam KHI bermula dari hukum adat. Ahli waris pengganti dalam hukum adat merupakan adopsi dari hukum perdata $(B W)$ Belanda. Sedangkan hukum perdata Belanda berasal dari Code Civil Napoleon di Perancis. Hukum perdata Perancis merupakan turunan dari hukum Romawi.

Di sisi lain, ahli waris pengganti dalam KHI dikemukakan oleh Hazairin. Beliau berdalih bahwa ahli waris pengganti bersumber dari al-Qurān surat an-Nisa' ayat 33 sebagaimana telah dikemukakan. Terhadap ayat ini Hazairin menjelaskan sebagai berikut:

“Nashibahum saya terjemahkan sebagai bagian kewarisan, yaitu sesuatu bagian dari harta peninggalan, beralaskan pemakaian kata nashi $b$ itu didalam ayat kewarisan lainnya, yaitu dalam Qur'an IV: 7, selain

${ }_{28}$ Moh. Dja'far, Polemik Hukum Waris, Kencana Mas, Cet. 1, Jakarta, 2007, hal. 83-84.

29 Wirjono Prodjodikoro, Hukum Kewarisan di Indonesia, Sumur, Bandung, 1983, hal. 51. 
hubungannya sendiri dalam ayat 33 itu dengan "mimma taraka" dan sebagainya. Di dalam ayat 33 itu jelas bahwa nashīb itu disuruh berikan kepada mawāli itu dan bukan kepada orang yang tersimpul dalam likullin, sehingga mawāli itu adalah ahli-waris. Untuk menangkap maksud ayat 33 itu, coba kita lihat isi likullin itu dengan li Fulänin, dan ja'alnā diganti dengan ja'ala llāhu, sedangkan urusan perjanjian itu untuk gampangnya ditinggalkan saja, maka bunyi ayat menjadi "wa li Fulānin ja'ala'llāhu mawālia mimmā taraka 'twālidāni wa 'läqrabūna, fa àtūhum nashïbahum".

Disini si pewaris ialah ayah atau mak atau seorang-orang dari aqrabūn. Jika ayah atau mak yang mati maka istilah-istilah itu mempunyai timbalan berupa anak, anak yang mati ataupun anak yang menjadi ahli waris karena masih hidup. Jika tidak ada anak-anak, baik anak-anak yang mati terlebih dahulu maupun anak-anak yang masih hidup pada saat matinya si pewaris, maka si pewaris itu bukan ayah atau mak tetapi seorang dari pada aqrabūn. Kepada anak-anak yang hidup telah pasti mesti diberikan nashibnya sebagai ahli-waris menurut IV: $11 a, b, c$, tetapi disamping nashib bagi anak-anak ini mesti pula diberikan nashīb kepada mawāli yang diadakan Allāh bagi si Fulān, dengan lain perkataan mawāli si Fulān ikut serta sebagai ahli-waris bagi ayah atau mak dan bukan si Fulān sendiri. Apa hubungan si Fulān dengan "mak atau ayah" yang mati itu, sehingga mawāli bagi si Fulān itu ikut pula menjadi ahli-waris bagi "mak atau ayah" itu sedangkan si Fulān sendiri tidak ikut menjadi ahli-waris? Berdasarkan prinsip umum bahwa Qur'ān meletakkan hubungan kewarisan atas dasar pertalian darah antara si-mati dengan anggota keluarganya yang masih hidup, maka si Fulān itu hanya dapat saya pikirkan sebagai anggota keluarga yang telah mati terlebih dahulu dari si pewaris, sedangkan mawāli si Fulān itu sebagai ahli waris bagi "ayah atau mak" itu hanya dapat saya pikirkan sebagai keturunan yang bukan anak bagi "ayah atau mak" itu. Hubungan antara si Fulān dan mawālinya, dalam hal mak atau ayah sebagai pewaris, hanya dapat dipikirkan ketiga jurusan, yaitu mawālinya itu mungkin seorang dari wālidānnya, dalam hal mana si Fulān sendiri adalah pula keturunan bagi "mak atau ayah" itu; ataupun mungkin awlādnya, ataupun lebih jauh aqrabūnnya, dalam hal mana si Fulān sendiri adalah juga keturunan bagi "ayah atau mak" itu. Menurut jalan pikiran itu maka si Fulān itu, dalam hubungan "ayah atau mak" sebagai pewaris, termasuk keturunan bagi "ayah atau mak", sedangkan mawāli bagi si Fulān itu juga keturunan bagi "ayah dan mak" itu, tetapi bukan anak bagi ayah dan mak itu. Tetapi anak yang telah mati terlebih da- 
hulu. Maka hubungan si Fulān dan mazwālinya itu adalah hubungan si pewaris dengan keturunannya melalui mendiang anaknya si Fulān itu. Kebenaran konklusi tersebut hanya dapat diujikan kepada ayat-ayat Qur'ān yang membicarakan kewarisan bagi seseorang yang ada meninggalkan anak (walad) yaitu IV: $11 \mathrm{a}, \mathrm{b}, \mathrm{c}, \mathrm{d}$, dengan dibandingkan pula dengan ayat-ayat Qur'ān yang membicarakan kewarisan bagi seseorang yang tidak ada baginya walad, yaitu IV: $11 e, f$, IV: $12 f, g$ dan IV: 176. Jika tidak ada ketentuan Qur'ān mengenai mawāli dalam IV : $33 a$ itu, maka bilamana seseorang pewaris hanya meninggalkan keturunan yang bukan walad bagi dia, karena keturunan itu adalah cucu atau piut bagi si pewaris dari kelahiran via mendiang anak-anak si pewaris, maka akan berlakulah atas harta peninggalannya itu IV: $11 e, f, \mathrm{IV}: 12 f, g$ dan IV : 176, sehingga cucu-cucu dan piut-piut itu akan tersingkir dari kewarisan dan hanya dipandang sebagai $\bar{u} l \bar{u}$-lqurbā saja (IV : 8) dalam berhadapan dengan orang tua dan saudara-saudara si pewaris yang akan berbagi harta peninggalan itu. Keadaan yang serupa ini akan bertentangan dengan seluruh fitrah yang ditanamkan Allāh dalam sanubari manusia, sehingga tidak ada sistem apapun yang akan dapat membenarkannya. Dari sudut cahaya ini, maka IV: $33 a$ itu termasuk rahmat yang sebesar-besarnya, yang telah diberikan Allāh kepada ummatNya. Jika tidak ada rahmat tersebut, maka apakah lagi dasar hukum yang dapat disalurkan dari Qur'ān untuk mendirikan hak kewarisan bagi lain-lain aqrabūn yang tidak tersebut dalam ayat-ayat kewarisan dalam Qur'ān, seperti paman dan bibik, datuk dan nenek, cucu dan piut, d.s.b.". ${ }^{30}$

Menurut uraian di atas, setelah mudhäf ilaih kata kullun yang ada dalam ayat itu dihilangkan dan diganti wa lifulānin, dan kemudian kata ja'alnā diganti dengan ja'alalläh sehingga berbunyi:

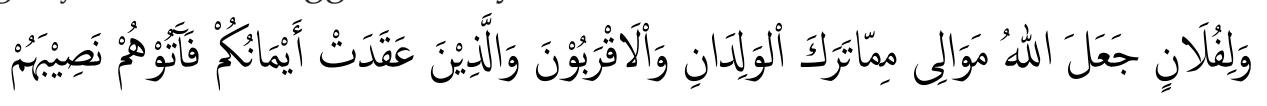

Terjemahan bebas teks ini menurut beliau adalah:

“Allah mengadakan mawāli untuk si fulan dari harta peninggalan orang tua dan keluarga dekat (serta allazîna 'aqadat aimânukum), maka berikanlah kepada mawāli itu (hak yang menjadi) bagiannya". ${ }^{31}$

30 Hazairin, Op cit, hal. 27-29.

31 Ibid, hal. 30. 
Fulan dianggap sebagai ahli waris, karena diiringkan dengan kata al-wālidān dan al-aqrabūn yang menjadi pewaris. Akan tetapi fulan tersebut mempunyai mawāli yang juga berhak mewarisi. Dalam keadaan yang menjadi pewaris adalah orang tua (ayah atau ibu) maka menurut Hazairin, ahli waris adalah anak dan atau mawāli anak. Jika anak-anak itu masih hidup maka sudah tentu merekalah yang berhak mewarisi harta orang tuanya berdasarkan al-Qur'ān surat ke-4 (an-Nisa') ayat 11. Sedangkan dalam al-Qur'ān surat ke-4 (an-Nisa') ayat 33 ada pula mawāli dari anak yang berhak menerima warisan. Mawāli disini hanya mungkin dipikirkan sebagai keturunan dari anak yang telah meninggal terlebih dahulu. Tidak ada kemungkinan lain selain dari mengartikan mawāli dengan keturunan dari anak yang telah meninggal dunia, karena hanya dalam keadaan seperti itulah posisi ayah sebagai pewaris tidak akan bertukar. Hal ini lebih dikuatkan lagi karena Allah dalam surat ke-4 (an-Nisa') ayat 33 menggunakan kata ja'ala yang semakna dengan khalaqa untuk menetapkan mawālî, yaitu menciptakan dari tidak ada menjadi ada. Dalam hukum kewarisan, proses penciptaan itu hanya dapat dibayangkan melalui kelahiran, sehingga ada hubungan antara pihak yang diangkat sebagai mawāli dan orang yang menjadi ahli waris tersebut. Penetapan ini tidak mungkin melalui cara lain, misalnya penunjukan. ${ }^{32}$

Untuk menguatkan alur berpikir di atas, Hazairin mengujinya dengan ayat-ayat kewarisan yang lain, yaitu al-Qur'ān surat ke-4 (an-Nisa') ayat 11, 12, dan 176. Berdasarkan ketiga ayat ini, jika seseorang meninggalkan cucu dari anak yang telah meninggal terlebih dahulu bersama-sama dengan saudara dan orang tua, maka cucu tersebut akan tersingkir, dan yang berhak mewarisi hanyalah orang tua dan saudara-saudara dari yang meninggal terlebih dahulu itu. Oleh sebab itu, keadaan yang serupa ini akan bertentangan dengan seluruh fitrah yang ditanamkan Allah dalam sanubari manusia. ${ }^{33}$

Menurut Hazairin, kata al-wālidāni wa al-aqrbūna adalah sebagai fa'il dari kata taraka. Sedangkan kata mawāli adalah sebagai maf'ul bagi ja'alna. ${ }^{34}$ Artinya, bahwa setiap harta peninggalan yang ditinggalkan oleh ibu bapak dan kerabat terdekat, dijadikan Allah ahli wari-ahli warisnya. Hal ini berarti bahwa yang

32 Ibid, hal. 31.

33 Ibid, hal. 29.

34 Moh. Toha Yahya Umar dkk, Perdebatan dalam Seminar Hukum Nasional 1963 Tentang Faraid, Tinta Mas, Djakarta, 1964, hal. 49. 
dijadikan Allah ahli waris-ahli waris tersebut adalah sebagai pengganti ahli waris yang telah meninggal dunia terlebih dahulu. ${ }^{35}$

Kata mawāli dimaksudkan oleh Hazairin dengan ahli waris pengganti dari mendiang anak, mendiang saudara, mendiang datuk atau nenek yang meninggal lebih dahulu sebelum pewaris. Menurut Hazairin, dalam berbagai kitab tafsir, kata mawāli diartikan semata-mata sebagai ahli waris langsung, sehingga semua kitab tafsir itu tidak ada gunanya. Hal ini disebabkan bahwa para penafsir mengartikan ayat mawāli itu "hanya jika ada mayat maka ada ahli waris langsungnya". Tidak terpikir oleh para mufassir itu bahwa ada kalanya ahli waris langsung itu sudah tidak ada. Akan tetapi Allah dalam al-Qur'ān surat ke- 4 (an-Nisa') ayat 33 mengadakan ahli waris lain, dalam hal ini ahli waris tidak langsung, yaitu ahli waris pengganti. ${ }^{36}$

Menelusuri pemikiran Hazairin di atas, maka ahli waris pengganti itu disamakan kedudukannya dengan ahli waris yang digantikannya. Orang yang digantikan itu adalah sebagai pengganti antara ahli waris (pengganti) dengan pewaris (orang yang meninggal dunia terlebih dahulu dan meninggalkan harta warisan). Berdasarkan hal itu, maka ahli waris pengganti (mawāli) adalah keturunan (anak) pewaris, baik laki-laki maupun perempuan, saudara pewaris (laki-laki dan perempuan) maupun leluhur orang yang meninggal dunia sebagai pengganti dari ayah dan ibu. ${ }^{37}$ Bila dikaitkan dengan ahli waris pengganti dalam KHI, terdapat kesamaan dengan pemikiran Hazairin dalam menafsirkan ayat 33 surat an-Nisa'.

\section{Perkembangan ahli waris pengganti}

Ahli waris pengganti dalam KHI sebelumnya sudah menjadi living law dalam masyarakat. Hal ini berdasarkan kebijakan pemerintah Hindia Belanda, termasuk Christiaan Snouck Hurgronje, Belanda berusaha untuk menyatukan bangsa Indonesia, baik secara asosiasi maupun asimilasi. Keduanya bertujuan agar bangsa Indonesia dapat menyatu dengan Belanda, terutama dalam unifika-

35 Hazairin, Op cit, hal. 30.

${ }^{36}$ Moh. Toha Yahya Umar dkk, Op cit, hal. 93.

37 Ibid, hal. 37. 
si hukum. Snouck berulang kali mengatakan bahwa pondasi Kerajaan Belanda diperkokoh oleh asosiasi orang Indonesia dengan kebudayaan Belanda. ${ }^{38}$

Politik hukum yang dikembangkan oleh pemerintah Hindia Belanda tertanam dalam pikiran masyarakat Indonesia. Bahkan ada kesan bahwa keadaan tersebut sudah berlangsung sejak tahun $1855 .{ }^{39}$ Konsep ahli waris pengganti yang dikembangkan oleh pemerintah Hindia Belanda di Indonesia, diduga kuat berasal dari hukum Belanda dan secara bertahap menjadi hukum adat dalam kehidupan masyarakat Indonesia. Hal ini terbukti dari penelitian Ter Haar Bzn dan Soepomo, bahwa dalam hukum adat waris Jawa Barat mengenal istilah ahli waris pengganti dengan sebutan "penggantian kedudukan" . ${ }^{40}$

Perkembangan ahli waris pengganti dapat dilihat dari penyelesaian kasus kewarisan, baik melalui musyawarah di antara ahli waris, musyawarah lembaga adat, putusan pengadilan Negeri dan putusan pengadilan Agama. Kasus ahli waris pengganti yang diselesaikan melalui musyawarah ahli waris, di antaranya kasus Jaruddin yang meninggal tahun 1992 di Banawa, dengan meninggalkan harta warisan dan ahli waris. Ahli waris yang ditinggalkan: seorang anak laki-laki, dua orang cucu laki-laki melalui anak laki-laki yang meninggal terlebih dahulu, dan seorang cucu perempuan dari anak perempuan yang meninggal terlebih dahulu dari pewaris. Harta yang ditinggalkan terdiri dari sebuah rumah, kebun kapok 462 pohon, dan tanah perumahan $424 \mathrm{~m}^{2}$.

Musyawarah di antara para ahli waris dilakukan berdasarkan prinsip hukum Islam yang mencerminkan keadilan. Keadilan dimaksud adalah dengan menafsirkan bahwa cucu perempuan dari anak perempuan dianggap sebagai ahli waris yang menggantikan kedudukan anak perempuan.

Hasil Musyawarah tersebut adalah, seorang cucu perempuan mendapat bagian sebuah rumah, seorang anak laki-laki menerima bagian kebun kapok 231 pohon dan tanah perumahan $212 \mathrm{~m}^{2}$. Dua orang cucu laki-laki dari anak laki-laki menerima bagian kebun kapok 231 pohon, dan tanah perumahan $212 \mathrm{~m}^{2} .^{41}$

38 Aqib Suminto, Politik Islam Hindia Belanda, LP3ES, Cetakan 1, Jakarta, 1985, hal. 39.

39 Sajuti Thalib, Op cit, hal. 39.

40 R. Otje Salman, Kesadaran Hukum Masyarakat Terhadap Hukum Waris, Alumni, Cet.2, Bandung, 2007, hal. 61. Eman Suparman, Hukum Waris Indonesia, PT. Refika Aditama, Cet.2, Bandung, 2007, hal. 64.

41 Zainuddin Ali, Op cit, hal. 165-166. 
Penyelesaian kasus di atas bahwa cucu laki-laki dari anak laki-laki ditetapkan sebagai ahli waris pengganti, dan begitu juga seorang cucu perempuan dari anak perempuan yang sudah meninggal lebih dahulu dari pewaris, ditetapkan sebagai ahli waris menggantikan kedudukan orang tuanya (ibu).

Hasil musyawarah para ahli waris tidak membedakan antara cucu yang berasal dari anak perempuan dan cucu yang berasal dari anak laki-laki. Demikian pula cucu yang berhak menggantikan kedudukan ahli waris yang meninggal terlebih dahulu, tidak membedakan antara cucu laki-laki dan cucu perempuan.

Bentuk kedua penyelesaian pembagian kewarisan adalah melalui musyawarah dewan adat. Cara ini dipakai karena para ahli waris tidak berhasil membagi harta warisan berdasarkan musyawarah di antara mereka. Kegagalan ini disebabkan kesalahpahaman mengenai harta yang diperoleh salah seorang ahli waris ketika orang tua mereka masih hidup, dan ada pula yang disebabkan oleh seorang ahli waris menginginkan pembagian yang lebih banyak dari ahli waris lainnya. ${ }^{42}$ Contoh kasus yang diselesaikan oleh dewan adat adalah Tjado yang meninggal tahun 1990 di Banawa. Harta yang ditinggalkan adalah berupa sebuah rumah dan kebun kelapa 750 pohon, sedangkan ahli warisnya terdiri dari dua orang anak laki-laki dan seorang cucu laki-laki dari anak lakilaki. Hasil kebun kelapa lebih banyak diambil oleh anak laki-laki yang terakhir atas dasar wasiat dari pewaris, sehingga anak laki-laki yang tertua mengajukan pembagian kewarisan kepada dewan adat di Desa Watatu.

Pada musyawarah tersebut, dewan adat menerapkan hukum Islam, yaitu bahwa wasiat pewaris yang tidak dapat dibuktikan oleh penerima wasiat dibatalkan oleh dewan adat. Cucu laki-laki dari anak laki-laki yang meninggal lebih dahulu dari pewaris mendapat bagian sebuah rumah serta kebun kelapa 50 pohon. Dua orang anak laki-laki mendapat bagian masing-masing 350 pohon kelapa. Bagian ahli waris pengganti sama dengan bagian ayahnya sekiranya dia masih hidup. Pembagian kewarisan tersebut disetujui oleh ahli waris karena tokoh agama yang menyampaikan itu mengatakan bahwa "pewaris yang sudah dikuburkan menjadi tenang rohnya dalam kubur bila ahli warisnya membagi harta warisan berdasarkan hukum Islam". ${ }^{43}$

\footnotetext{
42 Ibid, hal. 176.

43 Ibid, hal. 179-180.
} 
Kasus yang diselesaikan oleh dewan adat di atas, ahli waris pengganti mendapat bagian yang sama besarnya dengan ahli waris yang digantikannya sekiranya dia masih hidup. Pembagian yang diterima oleh ahli waris pengganti sama dengan ketentuan pada pasal 185 KHI. Selain itu, dewan adat beranggapan bahwa penyelesaian waris yang menetapkan adanya ahli waris pengganti adalah berdasarkan hukum Islam. Hal ini sebagai bukti pengaruh kebijakan pihak kolonial Belanda terhadap hukum di Indonesia.

Bentuk ketiga penyelesaian pembagian kewarisan adalah melalui pengadilan Negeri. Di antara kasus ahli waris pengganti adalah perkara yang terjadi antara Ny. Tasmiah melawan H. Rusni H. Kando, dkk, dengan nomor perkara: 32/Pdt.G/1993/Pn Palu, tanggal 28 September 1993. Ny. Tasmiah adalah sepupu satu kali dari H. Rusni H. Kando, yang belum mendapat bagian kewarisan ketika kakeknya meninggal dunia (sebagai ahli waris pengganti), sehingga dia menggugat ke Pengadilan Negeri Kabupaten Donggala untuk memperoleh hak kewarisan.

Pada gugatan itu dinyatakan bahwa H. Abdul Malik meninggal tahun 1959 di Tawaeli. Ahli waris terdiri dari empat cucu laki-laki dan tiga cucu perempuan dari seorang anak laki-laki, serta seorang cucu perempuan melalui anak perempuan. Harta warisan adalah berupa 63 hektar kebun kelapa.

Pihak penggugat mengemukakan bahwa harta peninggalan $\mathrm{H}$. Abdul Malik belum dibagi, sehingga tergugat yang menguasai harta itu bertentangan dengan hukum adat Kaili. Karena itu penggugat menginginkan pembagian kewarisan berdasarkan hukum adat Kaili. Pihak tergugat mengemukakan bahwa harta warisan yang dikuasai adalah harta ayahnya sebagai warisan dari $\mathrm{H}$. Abdul Malik.

Berdasarkan gugatan penggugat dan jawaban tergugat serta bukti yang dikemukakan, hakim bersidang hingga 12 kali. Putusannya adalah, ahli waris pengganti dari anak laki-laki menerima 41 hektar dan ahli waris melalui anak perempuan mendapat bagian 22 hektar. $^{44}$

Lembaga penggantian kedudukan (ahli waris pengganti) dikenal hampir di seluruh Provinsi Jawa Barat. ${ }^{45}$ Penggantian kedudukan/tempat terjadi apa-

44 Ibid, hal. 191-192.

45 Kecuali di daerah Cikoneng Kecamatan Kertasemaya Indramayu. Eman Suparman, Op cit, hal. 64. 
bila seseorang ahli waris meninggal terlebih dahulu dari si pewaris. ${ }^{46}$

Seorang anak yang meninggal terlebih dahulu dari orang tuanya, maka hak anak tersebut sebagai ahli waris dapat digantikan oleh anaknya (cucu pewaris). Ketentuan ini dipakai oleh adat daerah Leuwiliang, Cileungsi, Banjar, Ciamis, Kawali, Cianjur, Bandung, Pandeglang, Karawang, Indramayu dan Bekasi. Dapat pula digantikan oleh saudara pewaris, seperti yang berlaku di wilayah Ciamis, Cianjur, Banjar, Cisarua, dan Kawali. Selain itu, ada pula seseorang cucu menerima bagian berdasarkan rasa kasih sayang dari para ahli waris yang ada (saasihna). ${ }^{47}$

Yurisprudensi tentang penetapan ahli waris ini, pada prinsipnya menyatakan bahwa suatu gugatan penetapan ahli waris dapat dikabulkan apabila tergugat mengakui atau tidak membantah atau tidak menyangkal penggugat sebagai ahli waris. ${ }^{48}$ Di antara putusan hakim Pengadilan Negeri yang mengabulkan ahli waris pengganti sebagai ahli waris yang menggantikan kedudukan orang tuanya adalah Putusan Nomor 6/1973/Perd/Pn.Cn, Putusan Nomor 181/1974/Perd Pn. Cn, dan Putusan Nomor 84/1974/Pn. Cn. ${ }^{49}$

Sebelum KHI diberlakukan, putusan Pengadilan Agama dalam kasus ahli waris pengganti diakui sebagai ahli waris yang berhak. Sebagai contoh dapat diuraikan penyelesaian kasus ahli waris pengganti, yaitu perkara Nomor 247/ Pdt.V/1990/PA Palu tanggal 16 Agustus 1990. Pemohon Amboelo dkk. memohon penetapan ahli waris sebagai pengganti orang tuanya yang terlebih dahulu meninggal. Pewaris dalam hal ini adalah Indota yang meninggal tahun 1964. Indota mempunyai anak tiga orang, satu perempuan dan dua orang laki-laki. Anak perempuan mempunyai anak enam orang, tiga laki-laki dan tiga perempuan. Seorang anak laki-laki mempunyai dua orang anak laki-laki, dan seorang anak lakilaki yang lain mempunyai tiga orang anak laki-laki dan satu anak perempuan. Pengadilan Agama memutuskan bahwa enam orang cucu dari anak perempuan pertama berkedudukan sebagai ahli waris pengganti ibunya yang telah meninggal terlebih dahulu. Enam orang cucu dari anak laki-laki masing-masing meng-

46 Ibid.

47 Ibid, hal. 64-65.

48 Yurisprudensi Mahkamah Agung, Pengadilan Tinggi Jawa Barat di Bandung, Pengadilan Negeri Indramayu, Pengadilan Negeri Purwakarta dan Pengadilan Negeri Pandeglang. Ibid, hal. 65.

49 R. Otje Salman, Op cit, hal. 79. 
gantikan kedudukan ayahnya dalam mewarisi harta pewaris (kakek). ${ }^{50}$

Khusus mengenai pemberlakuan Pasal $185 \mathrm{KHI}$ tentang ahli waris pengganti, dapat diperhatikan putusan Hakim Pengadilan Tinggi Agama Pekanbaru Nomor: 05/Pdt.G/2010/PTA.Pbr., tanggal 25 Februari 2010. Penggugat dalam tingkat banding adalah Katidjem binti Matrejo melawan Ardem bin Mardenis Ahmat dkk (13 orang). Perkaranya berawal dari meninggalnya Ahmat bin Mulut alias Ahmat Gajah, dengan meninggalkan dua orang isteri, dan dua orang anak laki-laki. Seorang anak laki-laki bernama Mardenis bin Ahmat bin Mulut meninggal terlebih dahulu dari ayahnya (Ahmat bin Mulut), dengan meninggalkan 12 (dua belas) orang anak, laki-laki dan perempuan (cucu pewaris).

Hakim Pengadilan Tinggi Agama Pekanbaru membatalkan putusan Pengadilan Agama Kelas 1-A Pekanbaru Nomor: 0829/Pdt.G/2008/ PA. Pbr tanggal 18 Nopember 2009. Pengadilan Tinggi Agama Pekanbaru menetapkan bahwa Ahmat bin Mulut alias Ahmat Gajah telah meninggal dunia pada tanggal 08 Februari 2007 di Pekanbaru. Menetapkan ahli waris Ahmat bin Mulut, dan bagian mereka masing-masing sebagai berikut:

1). Dua orang isteri yaitu Hj. Mariana binti Kiman dan Katidjem binti Matrejo mendapat $1 / 8$, masing-masing menerima $1 / 16$ bagian yaitu $17 / 272$ $(6,25 \%)$;

2). Aljumrak bin Ahmat (anak laki-laki) menerima sisa ('ashabah) yaitu $7 / 16$ bagian atau 119/272 (43,75\%).;

3). Ardem bin Mardenis, cucu laki-laki dari anak laki-laki pewaris sebagai ahli waris pengganti menerima $14 / 272$ bagian atau $5,15 \%$;

4). Damra bin Mardenis, cucu laki-laki pewaris (ahli waris pengganti) mendapat $14 / 272$ bagian atau 5,15\%;

5). Darmarita binti Mardenis, cucu perempuan sebagai ahli waris pengganti mendapat $7 / 272$ bagian atau 2,57\%;

6). Armaida binti Mardenis, cucu perempuan sebagai ahli waris pengganti mendapat $7 / 272$ atau 2,57\%;

7). Radesma binti Mardenis, cucu perempuan sebagai ahli waris pengganti mendapat $7 / 272$ atau $2,57 \%$;

8). Winda Yuliani binti Mardenis, cucu perempuan sebagai ahli waris pengganti mendapat $7 / 272$ bagian atau $2,57 \%$;

50 Zainuddin Ali, Op cit, hal. 210-211. 
9). Alex Saputra bin Mardenis, cucu laki-laki sebagai ahli waris pengganti mendapat $14 / 272$ bagian atau $5,15 \%$;

10). Fitriyani binti Mardenis, cucu perempuan sebagai ahli waris pengganti mendapat $7 / 272$ bagian atau $2,57 \%$;

11). Fitriyanti binti Mardenis, cucu perempuan sebagai ahli waris pengganti mendapat $7 / 272$ bagian atau $2,57 \%$;

12). Damris bin Mardenis, cucu laki-laki sebagai ahli waris pengganti mendapat $14 / 272$ bagian atau 5,15\%;

13). Rusmini binti Mardenis, cucu perempuan sebagai ahli waris pengganti mendapat $7 / 272$ bagian atau $2,57 \%$;

14). Amhar bin Mardenis, cucu laki-laki sebagai ahli waris pengganti mendapat $14 / 272$ bagian atau $5,15 \% .^{51}$

Dari kasus yang dikemukakan di atas, pengadilan Tinggi Agama memberlakukan Pasal 185 KHI tentang adanya ahli waris pengganti. Pemberlakuan ahli waris pengganti sebenarnya telah terjadi pada hakim pengadilan Agama di tingkat pertama, tetapi disebabkan munculnya sengketa harta warisan maka penyelesaian kasusnya berlanjut ke tingkat banding.

Kedudukan ahli waris pengganti pada kasus itu adalah menggantikan kedudukan orang tua mereka yang telah meninggal terlebih dahulu dari pewaris. Hak yang mereka terima adalah hak kewarisan yang semestinya diterima oleh orang tua mereka. Meskipun orang tua mereka telah lebih dahulu meninggal dari pewaris, namun dianggap dia masih hidup, dan haknya itu diserahkan kepada anak-anaknya (cucu pewaris).

\section{Kedudukan Ahli Waris Pengganti}

Al-Qur'ān dan Sunnah Nabi merupakan dua sumber hukum utama yang meliputi seluruh aspek kehidupan manusia. ${ }^{52}$ Sebagai sumber hukum utama, al-Qur'an dari segi lafazh dan wurūd adalah qath'î. Sedangkan dari segi dilälah, ada yang qath' $\imath$ dan ada pula yang zhannī. ${ }^{53}$

Adapun Sunnah Nabi, ada yang qath'î dari segi wurūd atau sanādnya, yaitu kebenaran materinya datang dari Nabi dan qath'ì dari segi dilālah atau penun-

\footnotetext{
51 Arsip putusan diperoleh pada Pengadilan Tinggi Agama Pekanbaru, tahun 2012.

52 Al-Qur'an, Surat ke-16 (an-Nahl) ayat 89 dan Surat ke-6 (al-An'am) ayat 38.

53 Amir Syarifuddin, Ushul Figh, Jilid 1, Kencana, Cet. 4, Jakarta, 2009, hal. 58 dan 82.
} 
jukannya terhadap hukum. Akan tetapi yang terbanyak adalah zhannī dari segi wurūd dan dilālah atau dari segi keduanya. ${ }^{54}$

Dalam kaitannya dengan pembaruan hukum terhadap kedua sumber hukum utama tersebut, dapat dikategorikan menjadi dua, yaitu yang terbuka peluang untuk melakukan pembaruan melalui ijtihad dan yang sudah tertutup peluang untuk diperbarui. ${ }^{55}$

Aturan hukum yang tidak boleh diperbarui adalah hukum-hukum yang diketahui secara pasti dalam al-Qur'ān dan Sunnah Nabi, yaitu yang bersifat qath'i tsubùt atau wurūd dan qath'i dilālahnya, misalnya kewajiban shalat lima waktu, puasa, zakat, keharaman zina, mencuri, dan lainnya. ${ }^{56}$ Hukum yang terbuka peluang untuk melakukan pembaruan adalah yang bersifat zhannī wurūd atau tsubūt dan dilālahnya. ${ }^{57}$

Ahli waris pengganti yang telah menjadi living law atau 'urf dalam kehidupan masyarakat, baru dapat diterima jika tidak ada wahyu, berada di luar lingkup wahyu atau tidak bertentangan dengan wahyu. Sedangkan keberadaan ahli waris dalam hukum Islam sudah ditetapkan secara rinci dalam al-Qur'ān dan Sunnah Nabi, dan kemudian didasarkan pula kepada ijma' ulama.

Kata mawāli pada an-Nisa' ayat 33, selain qath'î tsubūt atau wurūd juga qath'i dilālah. Kepastian (qath'î dilālah) kata mawāli dibuktikan tidak adanya perbedaan pendapat para mufassir dalam menafsirkannya. Oleh sebab itu, tertutup peluang untuk mengadakan pembaruan hukum melalui ijtihad. ${ }^{58}$ Hukum adat juga tidak berpeluang sedikitpun untuk menggantikan nash yang sudah qath' $\hat{\imath}$ dilälah tersebut. ${ }^{59}$

54 Ibid, hal. 120 .

55 Saifuddin al-Amidi, Al-Ihkam fi Ushūl al-Ahkām, Muassisah al-Halbi, Juz IV, Kairo, tt, hal. 140.

${ }_{56}$ Wahbah Az-Zuhayli, dan Jamal Athiyah, Kontroversi Pembaruan Fiqh, Erlangga, Jakarta, 2002, hal. 113.

57 Ibid, hal. 114-115.

58 Hal ini sesuai kaedah: La masāgha li al-Ijtihād fi maurid an-Nash. Bila nash-nash itu bersifat zhannî, para ulama sepakat bahwa akal sangat berperan dalam melakukan interpretasi terhadapnya sebagai ruang lingkup ijtihad. Al-Ghazali, Abu Hamid Muhammad ibn Muhammad, Al-Mustasfā fi Ushūl al-Figh, Jilid II, Dār al-Fikr, Beirut, 1322H, hal. 367. Duski Ibrahim, Metode Penelitian Hukum Islam, Ar-Ruzz Media, Cetakan ke-1, Yogyakarta, 2008, hal. 100-101. Abdul Mun'in Saleh, Madhhab Syafi'i : Kajian Konsep Maslahah, Ittaqa Press, Yogyakarta, 2001, hal. 53.

59 Ayat-ayat kewarisan menurut Abd. Al-Wahhab al-Khallaf termasuk kategori nash 
Pelaksanaan hukum kewarisan harus memenuhi unsur, yaitu adanya orang yang telah meninggal dunia (pewaris), harta warisan, dan ahli waris yang berhak menerima warisan. Ahli waris berhak mewarisi bila ada di antara kerabat yang meninggal, tidak tertutup dan tidak terhalang.

Bila ditelusuri ahli waris pengganti dalam KHI, berarti bertentangan dengan unsur kewarisan itu sendiri. Proses kewarisan tanpa dilengkapi rukunrukun kewarisan, seperti ada pewaris mati, ada ahli waris hidup, dan ada harta peninggalan maka berarti tidak akan terjadi pewarisan. Akan tetapi menurut Pasal 185 KHI: ada pewaris mati, ada ahli waris yang mati lebih dahulu dari matinya pewaris. Hal ini kelihatannya lucu, karena kalau sudah mati tentu ia bukan ahli waris dari pewaris. Ahli waris yang mati lebih dahulu itu ketika matinya dulu tentu harta peninggalannya telah dibagi kepada ahli warisnya sendiri yang kini ia menjadi ahli waris pengganti. Masalah berhaknya ahli waris pengganti ini terhadap pewaris, adalah masalah tersendiri, mungkin bisa mewarisinya mungkin tidak, tergantung pada jenis hubungan darah dan kondisinya antara ahli waris pengganti ini dan pewaris. ${ }^{60}$

Keberadaan ahli waris pengganti juga bertentangan dengan teori tentang ahli waris. Atas dasar prinsip ijbari, khususnya dari segi kepada siapa harta itu beralih, sudah ditentukan secara pasti sebagaimana surat ke-4 (an-Nisa') ayat 7 sehingga tidak ada suatu kekuasaan manusia yang dapat mengubahnya dengan cara memasukkan orang lain atau mengeluarkan orang yang berhak. ${ }^{61}$ Adanya unsur ijbari kepada siapa harta itu diwariskan dapat dipahami dari kelompok ahli waris sebagaimana disebutkan Allah dalam al-Qur'ān surat ke-4 (an-Nisa') ayat 11, 12, dan 176.

Hukum kewarisan Islam mengakui adanya prinsip keutamaan dalam kekerabatan. Keutamaan dapat disebabkan oleh jarak hubungan antara ahli waris dengan pewaris. Keutamaan juga dapat disebabkan oleh kekuatan hubungan kekerabatan. Adanya perbedaan dalam kekerabatan ditegaskan oleh Allah dalam al-Qur'ān surat ke-8 (al-Anfal) ayat 75.

Adanya prinsip keutamaan terhadap hak kewarisan menyebabkan pihak

qath'î dilālah. Khallaf, Abdul Wahhaf, Mashādir al-Tasyri' fìmā lā Nash fìh, Dār al-Qalam, Kuwait, 1972, hal. 11. Imam Syaukani, Rekonstruksi Epistemologi Hukum Islam Indonesia, PT. Raja Grafindo Persada, Jakarta, 2006, hal. 228-229.

\footnotetext{
60 Mohd. Dja'far, Op cit, hal. 216-217.

${ }^{61}$ Habiburrahman, Op cit, hal. 193.
} 
kerabat tertentu tertutup. Hal ini berarti bahwa hukum kewarisan Islam mengenal adanya lembaga hijab. Hijab berarti tertutupnya seseorang yang berhak menjadi ahli waris disebabkan oleh ahli waris lain yang lebih utama darinya. ${ }^{62}$

Hijab terdiri dari dua macam, yaitu hijab hirman dan hijab nuqshan. Hijab Hirman adalah tertutupnya seseorang ahli waris untuk menerima hak kewarisan secara penuh, dalam arti tidak memperoleh sesuatupun. Salah satu hijab hirman itu adalah bahwa anak laki-laki menghijab semua cucu. Sedangkan dalam Pasal 185 KHI, cucu berhak mendapat harta warisan dikala terdapat anak lakilaki.

Aturan lembaga hijab merupakan realisasi dari asas ijbari, khususnya dari segi cara peralihan harta. Maksudnya bahwa harta pewaris beralih dengan sendirinya menurut kehendak Allah sesuai dengan sistem keutamaan dalam hubungan darah, bukan dialihkan oleh upaya seseorang. Oleh karena itu, kewarisan dalam Islam diartikan dengan "peralihan harta" yang mengandung pengertian ijbari sejalan dengan kehendak Allah. ${ }^{63}$

Ahli waris pengganti dalam KHI adalah mengubah ketentuan Allah, melanggar asas ijbari dari segi kepada siapa harta warisan itu beralih, dan memberikan hak warisan kepada orang yang telah meninggal dunia terlebih dahulu dengan upaya pengalihan kepada penggantinya. Jika peralihan hak waris dasarnya adalah ketentuan Allah, sedangkan pengalihan hak waris ketentuannya buatan manusia sebagaimana Pasal 185 KHI. Dengan kata lain, ahli waris pengganti merupakan hasil pemikiran yang tidak dilandasi oleh keimanan (syahadat), keadilan dan ketaqwaan, asas ijbari dalam teori tentang ahli waris, dan juga tidak dilandasi oleh sistem keutamaan dan hijab.

Sebagaimana dikemukakan bahwa semua mufassir mengartikan kata mawāli dengan ahli waris, bukan ahli waris pengganti. Hal ini sejalan dengan al-Qur'ān surat ke- 19 (Maryam) ayat 5 dan 6 yang berbunyi:

${ }^{62}$ Muhammad As-Siba'i, dan Abdurrahman as-Sabuni, Al-Ahwal al-Syakhshiyyah, Mudiriyah al-Kutub, Damaskus, 1961, hal. 509.

63 Habiburrahman, Op cit, hal. 193. 


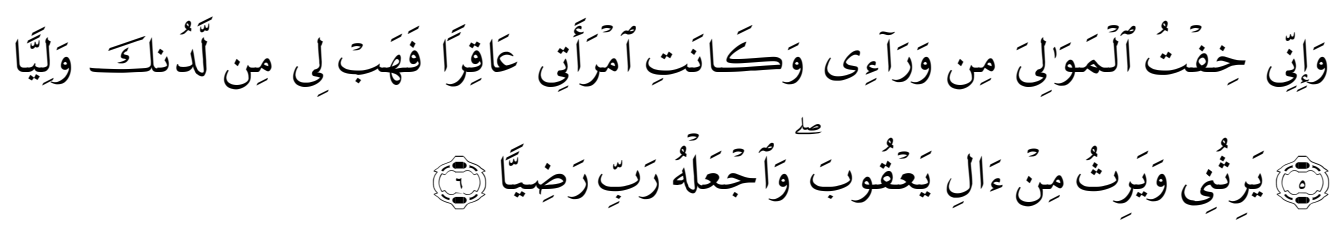

Artinya: Dan Sesungguhnya Aku khawatir terhadap mawāliku sepeninggalku, sedang isteriku adalah seorang yang mandul, Maka anugerahilah Aku dari sisi Engkau seorang putera. Yang akan mewarisi Aku dan mewarisi sebahagian keluarga Ya'qub; dan jadikanlah ia, Ya Tuhanku, seorang yang diridhai".

Kata Mawāli pada terjemahan al-Qur'ān Departemen Agama RI adalah orang-orang yang akan mengendalikan dan melanjutkan urusan Zakariya sepeninggalnya. Kekhawatiran Zakaria ialah kalau mereka tidak dapat melaksanakan urusan itu dengan baik, karena tidak seorangpun di antara mereka yang dapat dipercayainva, oleh sebab itu dia meminta dianugerahi seorang anak. ${ }^{64} \mathrm{Jadi}$, maksud kata mawāli adalah ahli waris, yaitu anak.

Kata mawāli juga dapat ditafsirkan oleh al-Qur'ān surat ke-4 (an-Nisa') ayat 7. Dalam ayat itu secara jelas bahwa laki-laki dan perempuan, yaitu mawāli menurut ayat 33 mendapat bagian dari harta peninggalan ibu dan bapak serta karib kerabat yang terdekat. Dengan demikian dapat disimpulkan bahwa arti mawāli adalah ahli waris (langsung), bukan ahli waris pengganti sebagaimana dipahamkan oleh Hazairin.

\section{E. Penutup}

Kehadiran ahli waris pengganti yang terdapat dalam KHI dirumuskan melalui jalur yurisprudensi yang bersumber dari hukum adat. Ahli waris pengganti dalam hukum adat merupakan adopsi dari hukum perdata $(B W)$ Belanda. Sedangkan hukum perdata Belanda berasal dari Code Civil Napoleon di Perancis. Hukum perdata Perancis merupakan turunan dari hukum Romawi.

Ahli waris pengganti berkembang dalam menyelesaikan perkara-perkara kewarisan, baik pada tingkat ahli waris melalui perdamaian, tingkat

${ }^{64}$ Departemen Agama RI, Al-Qur'an dan Terjemahnya, CV. Toha Putra, Semarang, 1996, hal. 243 dan 532. 
musyawarah adat dan pada lembaga peradilan, yaitu pengadilan Negeri dan pengadilan Agama.

Keberadaan ahli waris pengganti merupakan budaya yang tidak dilandasi oleh keimanan (syahadat), bertentangan dengan prinsip keadilan, asas ijbari dalam teori ahli waris, tidak sejalan dengan unsur-unsur kewarisan dan juga bertentangan dengan prinsip keutamaan dan hijab. Dengan demikian, keberadaan ahli waris pengganti dalam KHI perlu ditinjau kembali.

\section{DAFTAR PUSTAKA}

Al-Qurān al-Karim

Abdurrahman, Kompilasi Hukum Islam di Indonesia, Akademika Pressindo, Jakarta, Cet. 4, 2004.

Ali, Mohammad Daud, Hukum Islam dan Peradilan Agama, PT. Raja Grafindo Persada, Jakarta, Cet. 1, 1997.

Ali, Zainuddin, Pelaksanaan Hukum Waris di Indonesia, Sinar Grafika, Cet. 1, Jakarta, 2008.

Amidi, al, Saifuddin, Al-Ihkam fi Ushūl al-Ahkām, Muassisah al-Halbi, Juz IV, Kairo, tt.

As-Siba'i, Muhammad, dan Abdurrahman as-Sabuni, Al-Ahwal Al-Syakhshiyyah, Mudiriyatu al-Kutub, Damaskus, 1961.

Budiono, Rachmad, Pembaruan Hukum Kewarisan Islam di Indonesia, PT. Citra Aditya Bakti, Bandung, Cet. 1, 1999.

Departemen Agama RI, Himpunan Peraturan Perundang-undangan dalam Lingkungan Peradilan Agama, Proyek Peningkatan Pelayanan Aparatur Hukum, Jakarta, 2004.

Direktorat Pembinaan Badan Peradilan Agama, Kompilasi Hukum Islam di Indonesia, Direktorat Pembinaan Badan Peradilan Agama Direktorat Jenderal Pembinaan Kelembagaan Agama Islam Departemen Agama RI, Jakarta, 1991/1992.

Dja'far, Moh., Polemik Hukum Waris, Kencana Mas, Cet. 1, Jakarta, 2007.

Ghazali,al, Abu Hamid Muhammad ibn Muhammad, Al-Mustasfā fi Ushūl alFiqh, Jilid II, Dār al-Fikr, Beirut, 1322H.

Habiburrahman, Rekonstruksi Hukum Kewarisan Islam di Indonesia, Kencana, Jakarta, Cetakan 1, 2011. 
Hasan Basri, dkk, Majalah Bulanan Mimbar Ulama, Dewan Pimpinan Majelis Ulama Indonesia, Edisi Bulan Juli 1992, Jakarta, 1992.

Hazairin, Hukum Kewarisan Bilateral Menurut Qur'an dan Hadith, Tinta Mas, Jakarta, Cet. 5, 1981.

Ibrahim, Duski, Metode Penelitian Hukum Islam, Ar-Ruzz Media, Cetakan ke-1, Yogyakarta, 2008.

Imam Syaukani, Rekonstruksi Epistemologi Hukum Islam Indonesia, PT. Raja Grafindo Persada, Jakarta, 2006.

Khallaf, Abdul Wahhaf, Mashādir al-Tasyri' fìmā lā Nash fỉh, Dār al-Qalam, Kuwait, 1972.

Lathif, M. Djamil, Kedudukan dan kekuasaan Peradilan Agama di Indonesia, Bulan Bintang, Cet. 1, Jakarta, 1983.

M, Hajar, Dimensi Hukum Kewarisan Islam di Indonesia, Suska Press, Cet. 1, Pekanbaru, 2008.

Nasution, Amin Husein, Hukum Kewarisan: Suatu Analisis Komparatif Pemikiran Mujtahid dan Kompilasi Hukum Islam, PT. Raja Grafindo Persada, Jakarta, 2012.

Prodjodikoro,Wirjono, Hukum Kewarisan di Indonesia, Sumur, Bandung, 1983.

Rofiq, Ahmad, Pembaharuan Hukum Islam di Indonesia, Gama Media, Cet. 1, Jakarta, 2001.

Saleh, Abdul Mun'in, Madhhab Syafi'i : Kajian Konsep Maslahah, Ittaqa Press, Yogyakarta, 2001.

Salman, R. Otje, Kesadaran Hukum Masyarakat Terhadap Hukum Waris, Alumni, Cet.2, Bandung, 2007.

Subekti, R, dan R. Tjitrosudibio, Kitab Undang-Undang Hukum Perdata, Pradnya Paramita, Cetakan ke-40, Jakarta, 2009.

Suminto, Aqib, Politik Islam Hindia Belanda, LP3ES, Cetakan 1, Jakarta, 1985.

Suparman, Eman, Hukum Waris Indonesia, PT. Refika Aditama, Cet.2, Bandung, 2007.

Syarifuddin, Amir, Ushul Fiqh, Jilid 1, Kencana, Cet. 4, Jakarta, 2009.

Thalib, Sajuti, Receptio A Contrario (Hubungan Hukum Adat dengan Hukum Islam), Bina Aksara, Jakarta, cet. 4, 1985.

Umar, Moh. Toha Yahya dkk, Perdebatan dalam Seminar Hukum Nasional 1963 Tentang Faraid, Tinta Mas, Djakarta, 1964. 
Wignjosoebroto, Soetandyo, Dari Hukum Kolonial Ke Hukum Nasional, PT. Raja Grafindo Persada, Jakarta, Cet. 2, 1995.

Zuhayli, Az, Wahbah, dan Jamal Athiyah, Kontroversi Pembaruan Figh, Erlangga, Jakarta, 2002. 
170 Millah Vol. XIV, No. 1, Agustus 2014 